\title{
WILDFIRE DISEASE OF TOBACCO
}

\author{
E. D. GARBER \\ Department of Botany, University of Chicago, Chicago, Illinois
}

Received for publication December 19, 1960

Pseudomonas tabaci (Wolf and Foster) Stevens, produces an exotoxin, detectable as a bacteriumfree, chlorotic halo, surrounding the necrotic focus of infection in the leaf of a susceptible host at the site of inoculation (Braun, 1955). Garber and Heggestad (1958) reported that species of Nicotiana and varieties of Nicotiana tabacum differed in their susceptibility, ranging from highly susceptible to resistant, when leaves of plants grown in the greenhouse were inoculated with washed suspensions of this pathogen. Included in this series of host were three varieties or breeding lines of $N$. tabacum having wildfire resistance determined by a dominant gene transferred by hybridization from Nicotiana longiflora (Clayton, 1947; Heggestad and Clayton, 1955).

Relatively few cases of disease resistance in plants have been explained on the basis of a specific compound or compounds present in resistant hosts and absent in susceptible ones (Holton, 1959). In the absence of the humoral and cellular defense mechanisms commonly found in animals, it is reasonable to assume that plants resort to local biochemical or physiological mechanisms, once the pathogen has effected entry into the host. Garber (1960) has proposed a theory of pathogenicity which considered numerous mechanisms leading to resistance.

An investigation of the nature of resistance to wildfire disease of tobacco was undertaken on the assumption that the pathogen may be responsible for altering its microenvironment in the tobacco leaf at the site of inoculation.

\section{MATERIALS AND METHODS}

Cultures were grown in a defined medium containing ammonium-nitrogen (Vogel and Bonner, 1956) to which $1.5 \%$ agar was added whenever a solid medium was needed, or on a complex medium of nutrient agar supplemented with $0.5 \%$ yeast extract. Cultures were aerated either on a platform shaker at room temperature or in a tissue culture roller apparatus at $30 \mathrm{C}$. Strain PtR3 of $P$. tabaci was used throughout the investigation.
Plants of a number of species of Nicotiana and of varieties or breeding lines of $N$. tabacum were grown in the greenhouse from seed. Procedures for preparing inocula and for inoculating leaves have been presented by Garber and Heggestad (1958). To determine the number of viable bacterial cells at the site of inoculation, a disc of leaf tissue, punched out with a sterile cork borer ( $5 \mathrm{~mm}$ diameter), was homogenized in $2 \mathrm{ml}$ of sterile distilled water; suitable dilutions of the homogenate were plated on nutrient agar.

To obtain leaf juice, all but the two lowest leaves were removed from 4 to 5 plants of each variety or species, rinsed with sterile, distilled water, and rapidly dried by blotting. The petioles were removed and the intact blades were weighed. A sample weighing $50 \mathrm{~g}$ was wrapped in "Saranwrap" and immediately placed in a deep freeze for 1 to 4 days. Then the samples were removed, placed in a hydraulic press, and subjected to $10,000 \mathrm{psi}$. The expressed juice was collected, centrifuged at $5,000 \mathrm{rev} / \mathrm{min}$, and the $\mathrm{pH}$ of the supernatant determined with a Beckman Zeromatic $\mathrm{pH}$ meter. The buffering capacity was immediately determined by finding the volume of $0.05 \mathrm{~N} \mathrm{NaOH}$ required to bring 2 $\mathrm{ml}$ of the supernatant to $\mathrm{pH}$ 8.0. From these values, it was possible to calculate a buffer index.

\section{RESULTS}

Growth and $p H$ studies in vitro. The number of viable bacterial cells and the $\mathrm{pH}$ of cultures grown in liquid medium containing graded concentrations of yeast extract or acid-hydrolyzed casamino acids plus $1 \%$ glucose in distilled water were determined at intervals for 14 days; similar observations were made on cultures grown in the defined medium supplemented with the same concentrations of yeast extract or casamino acids. The results are summarized in Table 1 .

Cultures grown in the water-media exceeded $\mathrm{pH} 8.0$ within 4 days and exhibited a decrease in viable count. With continued incubation, they became increasingly alkaline and yielded fewer viable cells. Furthermore, seeded plates 
TABLE 1

$p H$ and viable count of cultures of Pseudomonas tabaci in four media

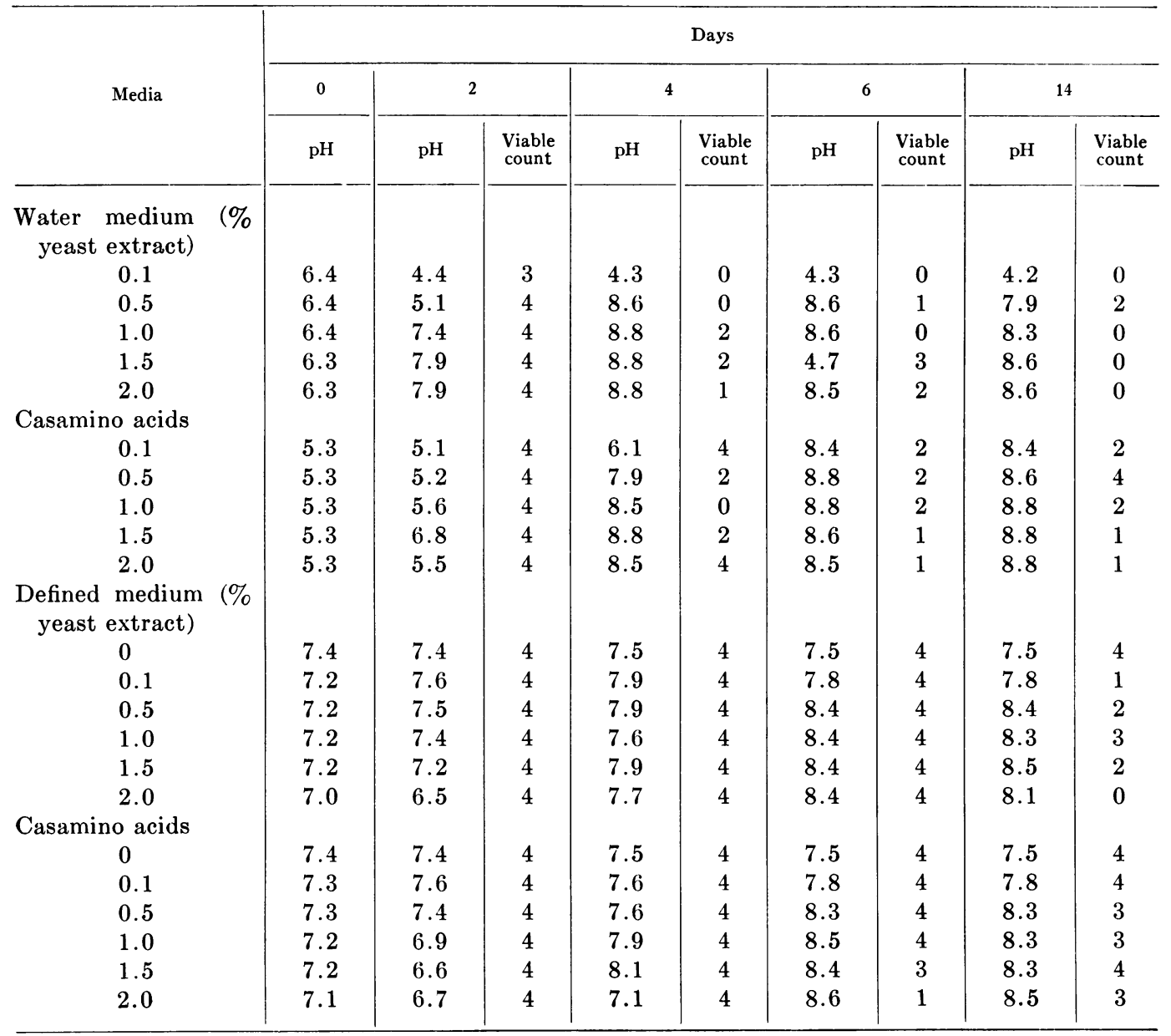

Inoculum $=1$ to $3 \times 10^{5}$ cells per $\mathrm{ml}$ of medium. Viable count was determined by seeding replicate plates with $0.1 \mathrm{ml}$ of the culture. $0=0$ to 400 colonies; $1=500$ to 1,000 colonies; $2=1,000$ colonies, almost confluent growth; $3=$ thin, confluent growth; 4 = heavy, confluent growth.

did not display colonies until 1 to 2 days after the control plates and colonies from the alkaline media were smaller and required more time to increase in diameter. Fluctuations in both number of viable cells and $\mathrm{pH}$ were observed during the course of the experiment. The unexpected $\mathrm{pH}$ readings for cultures containing $1.5 \%$ yeast extract in water on the sixth and eighth days may have resulted from an error in recording the observations.

Cultures grown in supplemented defined media also became increasingly alkaline but at a slower rate compared with cultures grown in watermedia. A decrease in the number of viable cells was noted after 14 days in the yeast extract- media but not in the casamino acids-m edia Fluctuations in both viable count and $\mathrm{pH}$ were observed after the first week of incubation. Control cultures grown in an unsupplemented defined medium maintained both viable count and $\mathrm{pH}$ throughout the experiment.

The defined medium was supplemented with individual amino acids, glutamine, asparagine, or urea to determine which compound(s) provided a substrate leading to alkalinity in cultures incubated for 7 days. The results, summarized in Table 2, indicated that cultures supplemented with alanine, arginine, glycine, serine, threonine, glutamine, asparagine, or urea exceeded $\mathrm{pH}$ 8.0. 
TABLE 2

pH of cultures grown for 7 days in defined medium supplemented with amino acids, amines,

or urea

\begin{tabular}{|c|c|c|c|c|c|}
\hline \multirow{2}{*}{ Compound } & \multicolumn{2}{|c|}{ Days } & \multirow{2}{*}{ Compound } & \multicolumn{2}{|c|}{ Days } \\
\hline & 0 & 7 & & 0 & 7 \\
\hline DL-Aspartic & 6.5 & 7.3 & DL-Alanine & 6.9 & 8.3 \\
\hline acid & & & L-Arginine & 6.9 & 8.2 \\
\hline L-Cysteine & 6.9 & 6.8 & Glycine & 6.8 & 8.2 \\
\hline DL-Gilu- & 6.5 & 7.3 & DL-Serine & 6.9 & 8.1 \\
\hline tamic acid & & & DL-Threo- & 6.9 & 8.2 \\
\hline DL-Histidine & 6.6 & 7.6 & nine & & \\
\hline DL-Hydroxy- & 6.9 & 7.4 & Asparagine & 6.8 & 8.3 \\
\hline proline & & & Glutamine & 6.9 & 8.4 \\
\hline $\begin{array}{l}\text { DL-Isoleu- } \\
\text { cine }\end{array}$ & 6.9 & 7.5 & Urea & 7.0 & 8.9 \\
\hline DL-Leucine & 6.8 & 7.5 & & & \\
\hline DL-Lysine & 6.9 & 7.5 & & & \\
\hline $\begin{array}{l}\text { DL-Methio- } \\
\text { nine }\end{array}$ & 6.8 & 7.3 & & & \\
\hline DL-Ornithine & 6.9 & 7.3 & & & \\
\hline $\begin{array}{l}\text { DL-Phenyl- } \\
\text { alanine }\end{array}$ & 6.9 & 7.4 & & & \\
\hline DL-Proline & 6.8 & 7.9 & & & \\
\hline DL-Tyrosine & 6.9 & 7.5 & & & \\
\hline DL-Valine & 6.8 & 7.7 & & & \\
\hline Control & 7.4 & 7.5 & & & \\
\hline
\end{tabular}

Compounds added to obtain terminal concentration of $2 \times 10^{-2} \mathrm{M}$.

Growth studies in vivo. Diachun and Troutman (1954) reported that $P$. tabaci multiplied in leaves of susceptible and resistant hosts and that the number of bacteria in susceptible leaves was greater than that in resistant leaves. These observations were confirmed, using $N$. longiflora as the resistant and $N$. sylvestris as the susceptible hosts (Table 3). The number of bacterial cells rapidly increased within 5 days after inoculation in leaves of the susceptible host but decreased in leaves of the resistant host. Although the number of cells fluctuated in leaves of the resistant host during the experiment, several sites of inoculation yielded no detectable bacteria after the fifth day.

$p H$ and buffer index of leaf juice. The $\mathrm{pH}$ and buffering capacity of leaf juice, expressed as a buffer index, from leaves of susceptible and resistant hosts are summarized in Table 4. The $\mathrm{pH}$ values ranged from 5.6 to 6.5 and it was not possible to relate these values with either
TABLE 3

Multiplication of Pseudomonas tabaci in leaves of a susceptible host (Nicotiana sylvestris) and of a resistant host (Nicotiana longiflora)

\begin{tabular}{r|c|l}
\hline $\begin{array}{c}\text { Days } \\
\text { after } \\
\text { Inocu- } \\
\text { lation }\end{array}$ & \multicolumn{2}{|c}{$\begin{array}{c}\text { No. of Bacteria Recovered from Replicate } \\
\text { Sites of Inoculation }\end{array}$} \\
\cline { 2 - 3 } & \multicolumn{1}{|c}{$N$ sylvestris } & \multicolumn{1}{|c}{ N. longiflora } \\
\hline 0 & $1 \times 10^{2},<1 \times 10^{2}$ & $2.3 \times 10^{3}, 6.0 \times 10^{5}$ \\
1 & $5.7 \times 10^{3}, 5.2 \times 10^{3}$ & $3.8 \times 10^{1}, 4.0 \times 10^{1}$ \\
3 & $3.4 \times 10^{6}, 7.6 \times 10^{6}$ & $6.6 \times 10^{2}, 1.7 \times 10^{4}$ \\
5 & $3.4 \times 10^{7}, 2.4 \times 10^{7}$ & $6.9 \times 10^{3}, 2.4 \times 10^{3}$ \\
7 & $4.7 \times 10^{7}, 1.1 \times 10^{7}$ & $6.3 \times 10^{3}, 0$ \\
9 & $2.0 \times 10^{6}, 6.3 \times 10^{7}$ & $5.1 \times 10^{2}, 0$ \\
11 & $1.3 \times 10^{6}, 1.1 \times 10^{7}$ & $1.8 \times 10^{3}, 0$ \\
15 & $1.1 \times 10^{7}, 9.6 \times 10^{7}$ & $7.5 \times 10^{1}, 0$ \\
\hline
\end{tabular}

TABLE 4

$p H$ and buffering capacity of juice expressed from leaves of susceptible and resistant hosts of Pseudomonas tabaci

\begin{tabular}{|c|c|c|c|c|c|}
\hline Susceptible Hosts & $\mathrm{pH}$ & $\mid$ & Resistant Hosts & $\mathrm{pH}$ & 总 \\
\hline $\begin{array}{l}\text { Nicotiana } \\
\text { debneyi }\end{array}$ & 5.6 & 9.5 & $\begin{array}{l}\text { Nicotiana } \\
\quad \text { longiflora }\end{array}$ & 5.8 & 6.1 \\
\hline $\begin{array}{l}\text { Nicotiana } \\
\quad \text { glutinosa }\end{array}$ & 5.9 & 9.2 & $\begin{array}{l}\text { Nicotiana } \\
\quad \text { longiflofa }\end{array}$ & 5.7 & 4.9 \\
\hline $\begin{array}{l}\text { Nicotiana } \\
\quad \text { raimondii }\end{array}$ & 5.9 & 7.1 & $\begin{array}{l}\text { Nicotiana } \\
\quad \text { longiflora }\end{array}$ & 5.9 & 4.6 \\
\hline $\begin{array}{l}\text { Nicotiana } \\
\quad \text { sylvestris }\end{array}$ & 5.6 & 7.9 & $\begin{array}{l}\text { Nicotiana } \\
\text { tabacum }\end{array}$ & & \\
\hline Nicotiana & 5.9 & 10.5 & Burley 21 & 6.5 & 6.5 \\
\hline $\begin{array}{l}\text { tomentosa- } \\
\text { formis }\end{array}$ & & & Bel 6-62 & 6.3 & 6.6 \\
\hline $\begin{array}{l}\text { Nicotiana } \\
\text { tabacum }\end{array}$ & & & & & \\
\hline Conn 49 & 6.0 & 8.3 & & & \\
\hline $\begin{array}{c}\text { Swarr-Hib- } \\
\text { schmann }\end{array}$ & 5.9 & 9.8 & & & \\
\hline Havana 142 & 5.9 & 11.9 & & & \\
\hline T.I. 170 & 6.1 & 7.1 & & & \\
\hline $\begin{array}{l}\text { Dixie De- } \\
\text { light } 101\end{array}$ & 6.2 & 8.9 & & & \\
\hline Catterton & 6.2 & 8.9 & & & \\
\hline Samsun & 5.8 & 9.2 & & & \\
\hline Smyrna & 5.9 & 9.4 & & & \\
\hline Wilson & 6.0 & 10.5 & & & \\
\hline Vamorr 50 & 6.1 & 12.2 & & & \\
\hline 402 & 6.0 & 11.0 & & & \\
\hline
\end{tabular}


susceptibility or resistance. The buffer index of juice from leaves of resistant hosts ranged from 4.9 to 6.6 and from leaves of susceptible hosts, from 7.1 to 12.2. According to these data, hosts yielding a buffer index less than 7.0 were resistant and those yielding values exceeding 7.0 were susceptible. In other words, juice from leaves of susceptible hosts had a greater buffering capacity than juice from resistant hosts.

\section{DISCUSSION}

The wildfire bacterium multiplies initially within the intercellular spaces of the leaf, not within the host cells (Hill, 1930). Presumably, the intercellular fluid provides a medium for the multiplication and metabolism of the pathogen. Aqueous leaf extracts from leaves of resistant hosts did not inhibit the multiplication of the bacterial cells (Garber, 1959). Although it is logical to assume that resistance may reflect an effective inhibitory environment in the host (Garber, 1956), there are no data to implicate either one or more compounds in resistant hosts not to be found in susceptible ones. Resistance to wildfire, however, may be transferred by hybridization from a resistant host to a susceptible host. For this reason, it seems reasonable to assume that a specific mechanism, under genetic control, is operating in the resistant but not in the susceptible hosts.

The increasing alkalinity and decreasing number of viable bacterial cells in poorly buffered medium containing certain nitrogenous compounds and the apparent stability in $\mathrm{pH}$ or number of viable cells in well buffered medium supplemented with the compounds suggested an explanation for the observations in vivo on multiplication of bacteria at the site of inoculation in leaves. Even the fluctuations in the number of viable bacteria in the resistant leaves were paralleled to some extent in poorly buffered media.

Although the juice expressed from leaves under high pressure cannot reflect either the composition or properties of the intercellular fluid, it was possible to distinguish between susceptible and resistant hosts on the basis of the buffering capacity of the expressed juice. Granting the assumption that the buffering capacity of the intercellular fluid may be related to that of the expressed juice, it is possible that susceptible hosts provide a well buffered medium and the resistant host, a poorly buffered medium for the pathogen. By using biochemical mutants of P. tabaci, Garber and Heggestad (1958) and Garber (1959) have demonstrated that the intercellular fluid of leaves of susceptible hosts probably contains glycine and arginine. It may be assumed that these and other nitrogenous compounds are also present in the intercellular fluid of leaves of resistant hosts.

By incorporating observations both in vitro and in vivo, it has been possible to propose a reasonable explanation for resistance to the wildfire pathogen. The bacteria enter the intercellular spaces of the leaf where they multiply and metabolize in the intercellular fluid. Since nitrogenous compounds are presumably present, the intercellular fluid may or may not become alkaline. In susceptible hosts, the fluid is sufficiently buffered to maintain a $\mathrm{pH}$ which is not inimical to the bacteria; in resistant hosts, the the fluid is poorly buffered and, in time, becomes sufficiently alkaline so that the multiplication and eventually viability of the cells are impaired. Consequently, the number of bacteria increases at the site of inoculation in susceptible leaves and diminishes in resistant leaves.

In the susceptible host, the exotoxin produced by the pathogen is responsible for the death of leaf cells adjacent to the site of inoculation (Braun, 1955). The moribund or dead cells contribute their contents to the site of inoculation and thereby help to maintain the buffering capacity of the intercellular fluid. It is difficult to detect the exotoxin by the characteristic chlorotic halo surrounding the site of infection in resistant leaves, even though some exotoxin must have been produced by the pathogen residing in the leaf for at least a week. According to Clayton (1934), the exotoxin is rapidly inactivated by exposure to a mild alkali. This observation lends support to the explanation that has been offered for resistance to wildfire, that is, increased alkalinity at the site of inoculation in resistant leaves.

According to the explanation for resistance to wildfire disease, the microenvironment (site of inoculation) of the pathogen may be altered as a consequence of the metabolic activity of the inoculum (Garber, 1960). If the host cannot maintain the original status of the $\mathrm{pH}$ of the microenvironment, it will be resistant; if the host can maintain the original status, it will be susceptible. A somewhat analogous situation in 
Brucella abortus has been reported by Goodlow, Mika, and Braun (1950). Certain smooth strains of this pathogen excrete alanine into the medium; when the concentration of this amino acid reaches certain levels, multiplication of the smooth cells is greatly inhibited. Furthermore, rough mutant cells which are resistant to these levels of alanine replace the smooth cells.

\section{ACKNOWLEDGMENTS}

This investigation was aided by a contract between the Office of Naval Research, Department of the Navy, and the University of Chicago, and by a grant from the Wallace C. and Clara A. Abbott Memorial Fund, University of Chicago. The technical assistance of Susan G. Shaeffer is gratefully acknowledged.

\section{SUMMARY}

The number of viable cells and the $\mathrm{pH}$ of cultures of Pseudomonas tabaci grown in four media were periodically determined during 14 days of incubation. In media containing graded concentrations of yeast extract or casamino acids plus $1 \%$ glucose in water, increasing alkalinity preceded a progressively diminishing number of viable cells. In well buffered, defined media supplemented with the same concentrations of yeast extract or casamino acids, the number of viable cells did not diminish signifcantly over the same period.

The number of viable cells at the site of inoculation in susceptible leaves increased rapidly and did not exhibit significant decreases during 14 days; in leaves of a resistant host, the number of viable cells decreased and, in some sites of inoculation, viable bacterial cells could not be detected.

The buffering capacity of juice from leaves of susceptible hosts was greater than that from leaves of resistant hosts. It was possible to relate resistance with a buffer index of less than 7.0 and susceptibility with an index greater than this value.

Resistance to the wildfire pathogen was explained on the basis of an alteration in $\mathrm{pH}$ of the intercellular fluid toward alkalinity as a con- sequence of the metabolic activity of the bacterial cells at the site of inoculation in the leaf.

\section{REFERENCES}

Braun, A. C. 1955 A study on the mode of action of the wildfire toxin. Phytopathol., $45,659-664$.

Clayton, E. E. 1934 Toxin produced by Bacterium tabacum and its relation to host range. J. Agr. Research, 48, 411-426.

Clayton, E. E. 1947 A wildfire resistant tobacco. J. Heredity, 38, 35-40.

Diachun, S., AND J. Troutman 1954 Multiplication of Pseudomonas tabaci in leaves of burley tobacco, Nicotiana longiflora, and hybrids. Phytopathol., 44, 186-187.

GaRBER, E. D. 1956 A nutrition-inhibition hypothesis of pathogenicity. Am. Naturalist, 90, 183-194.

Garber, E. D. 1959 Further observations on biochemical mutants of Pseudomonas tabaci. Botan. Gazette, 120, 157-161.

GARBER, E. D. 1960 The host as a growth medium. Ann. N. Y. Acad. Sci., 88, 11871194.

Garber, E. D., and H. E. Heggestad 1958 Observations on the pathogenicity of biochemical mutants of Pseudomonas tabaci. Phytopathol., 48, 535-537.

Goodlow, R. J., L. A. Mika, and W. Braun 1950 The effect of metabolites upon growth and variation of Brucella abortus. J. Bacteriol., 60, 291-300.

Heggestad, H. E., and E. E. Clayton 1955 Development of burley varieties of tobacco resistant to black shank, Fusarium wilt, wildfire, tobacco mosaic, and black root rot. Phytopathol., 45, 463 (abstr.).

Hill, J. B. 1930 The zoogloeae of Bacterium tabacum and their relation to the problem of the migration of bacterial phytopathogenes through the host tissues. Phytopathol., 20, 187-198.

Holton, C. E. (Editor) 1959 Plant pathology. The University of Wisconsin Press, Madison.

Vogel, H. J., ANd D. M. Bonner 1956 Acetylornithase of Escherichia coli: partial purification and some properties. J. Biol. Chem., 218, 97-106. 